\title{
PRODUCTION OF BIO-DIESEL FROM MICRO ALGAE GROWN IN WASTE WATER
}

\author{
J.Chandini ${ }^{1}$, Prakash Binnal ${ }^{2}$, P Nirguna Babu ${ }^{3}$ \\ ${ }^{1}$ Department of Chemical Engineering, Siddaganga Institute of Technology, Tumakuru 572103, Karnataka, India \\ ${ }^{2}$ Department of Chemical Engineering, Siddaganga Institute of Technology, Tumakuru 572103, Karnataka, India \\ ${ }^{3}$ Department of Chemical Engineering, Siddaganga Institute of Technology, Tumakuru 572103, Karnataka, India
}

\begin{abstract}
The objective of this study is to evaluate the growth of micro algae Chlorella protothecoides in various percentage of waste water sampled from different terminals in batch culture. Evaluation of the growth of the micro algae along with the lipid production is estimated. Parameters such as in chemical oxygen demand, growth curve of the algae and variation in elements nitrogen and phosphorous is investigated by the growth of the algae in waste water. The media used is the basal media for the cultivation of the algae. Waste water from the domestic treatment plant in the campus is obtained from the terminals grid chamber (1), aeration tank (2) and from the secondary clarifier(3). The maximum growth is observed to be in the 50\% waste water sampled from secondary clarifier with the biomass of $1.008 \mathrm{~g} / \mathrm{l}$. It is also seen that there is efficient reduction in COD, nitrogen and phosphorous leading to the treatment of waste water along with the secretion of lipid of 19\%. Hence the cultivation of Chlorella protothecoides can be adopted to grow in the waste water rich in nutrients that becomes economical as it do not require any fertilizers, media or fresh waters in specific for the bio diesel production without affecting the food chain of humans nor having any impact on the environment.
\end{abstract}

\section{INTRODUCTION}

There is a global shortage for the fossil fuels, specially oil and natural gas hence focus is over development of renewable bio fuel production. There is an immediate need to develop bio fuels because of depleting petroleum resources and increase in global energy demand. (Atefeh Ebrahimian, et al.,2014) Therefore the need for the bio fuel is the global issue as the fossil fuels are non renewable and unsustainable energy source. Additional cause for the focus on bio fuel is increase in the emission of large amount of carbon dioxide to the environment on burning the fossil fuels which has the tremendous effects on environment contributing to the green house effect. (Bharat Gamia et al..2014)

Bio fuel is the one which serves as the alternative and renewable source for the fossil fuels. Therefore a major focus is over the production of bio fuels and has attracted attention over the production of bio diesel. There are various sources which form the feedstock for the bio diesel production like algae, vegetables, animal fats, jatropa seeds, rape seed, soybean, castor oil, neem seeds, jojoba oil etc.(Farooq Ahmad et al..2013). Microalgae is considered as the potent stock for the bio diesel production as algae do not have any impact on the environment and non toxic and also do not harm the food chain despite vegetables. Microalgae requires large amount of water and nutrients for its growth which becomes ineffective for the cultivation. However it can also been grown in waste waters, ( Sheng-Yi Chiu et all..2015) sea waters which is rich in nutrients and salts which cuts the cost of cultivation conventionally. (Ashish Bhatnagar et al..,2011) Also on the other hand micro algae require carbon dioxide for its growth which leads to carbon dioxide fixation that reduces the green house gases. Algal strains from genus of chlorella have the highest net bio mass accumulation is observed with chlorella kessleri followed by chlorella protothecoides.

Micro algae Chlorella protothecoides are the group of chlorella species that are mixotrophic that could be cultivated under autotrophic as well as heterotrophic conditions that utilize inorganic and organic substrates for its growth that leads to the synergistic effects of lipid production along with the treatment of waste water.( Fiona Lynch et al..2015). This study is conducted to investigate the growth of Chlorella protothecoides in waste water of various percentages along with the basal media (Fatima Zahra Mennaa et al..2015).. Also to study the amount of removal of COD, nitrogen and phosphorous in the waste water leading to the treatment of waste water simultaneously lipid accumulation and eventually bio diesel production.

\section{MATERIALS AND METHODS}

\subsection{Algal culture and Waste Water Collection}

Waste water is collected from the treatment plant in the campus at different terminals such as grit chamber, aeration chamber and from the secondary clarifier(Liang Wang at al.). The basal media is prepared according to the composition given in the table(1), in which the micro alga is grown. Waste water with the combination of media is made for different percentages of waste water like $25 \%, 50 \%$, $75 \%$ and $100 \%$ waste water. Chlorella protothecoides is then inoculated into these combination of media - waste water as mentioned above. The samples were estimated for 
the growth of the bio mass for every $24 \mathrm{~h}$ and also analysed for the reduction in COD and nutrients nitrogen and phosphorous. From the data obtained the biomass growth curve was plot to see the adoption of microalgae to the various waste water samples prepared and studied the percentage of removal of the nutrients.

\subsection{Lipid Extraction and Estimation}

Blighdyer's method is followed for the lipid extraction process. The bio mass obtained from the combinations of waste water samples as mentioned is estimated for the percentage of lipid accumulation. There are several methods for the lipid extraction process like solvent extraction, supercritical fluid extraction, ultrasonic extraction and mechanical pressing.

In this study lipid extraction is achieved by the solvent extraction method. A known quantity of bio mass is added to the solvent methanol: chloroform in the ratio 1:2 and vortex for about 10mins followed by the separation of biomass from the solvent. The solvent now consists of the lipid which is given a water wash to remove the water soluble impurities and other proteins. The phase is now separated from the water. To this lipid solvent extract the transesterification reaction is carried out using sulphuric acid as the catalyst. After the reaction is over the bio diesel produced during the reaction is extracted again into hexane.

\section{RESULTS AND DISCUSSION}

The investigation of growth curve of the Chlorella protothecoides depicted that the algae is well adopted to grow in all the combinations of waste water sample with varying growth curves. $50 \%$ waste water combination i.e $50 \%$ waste water: $50 \%$ media, showed the best results among the other combinations $(25 \%, 50 \%, 75 \%, 100 \%$ waste water). Sample from the secondary clarifier is observed to be the best suited for the algal growth with the maximum bio mass of $1.5008 \mathrm{~g} / \mathrm{l}$. And lipid accumulation to be $19.36 \%, \%$ of removal of nitrogen and phosphorous is $87.5 \%$ and $68.18 \%$ respectively in the waste water sample.

Biomass growth rate: samples of secondary clarifier.

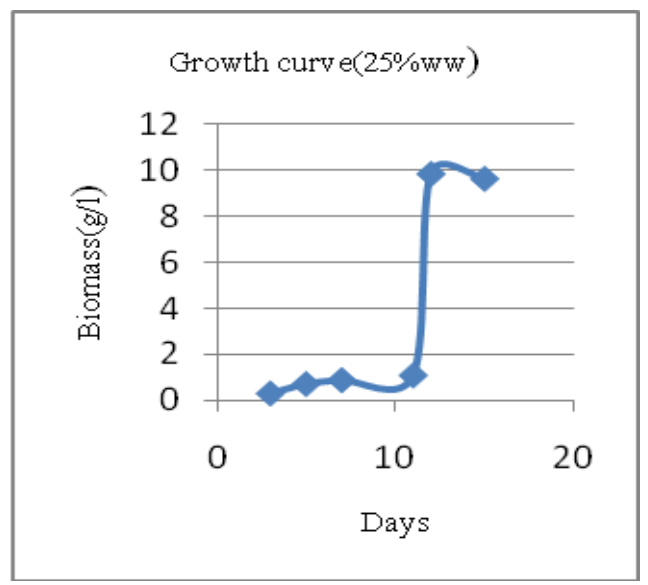

Fig 1: Showing the growth curve of $25 \% \mathrm{ww}=1.108 \mathrm{~g} / \mathrm{l}$

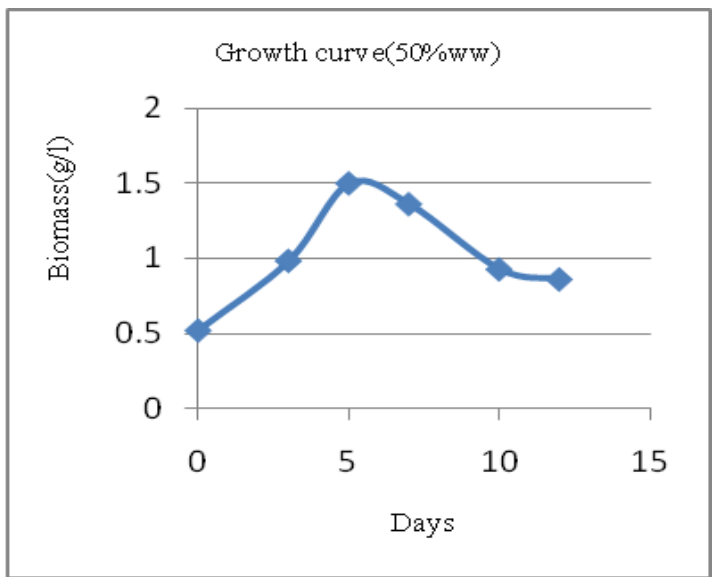

Fig 2 Showing the growth curve of 50\%ww $=1.5008 \mathrm{~g} / \mathrm{l}$.

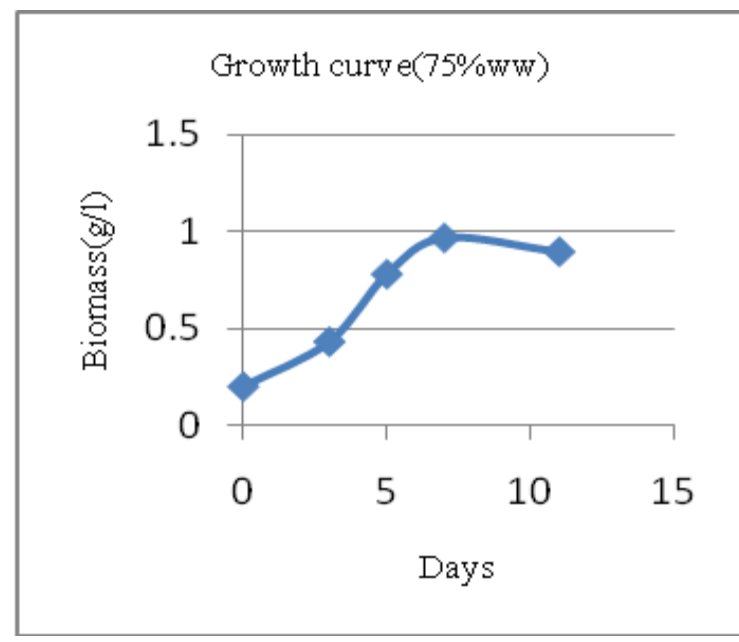

Fig 3 Showing the growth curve of $75 \% \mathrm{ww}=0.9647$

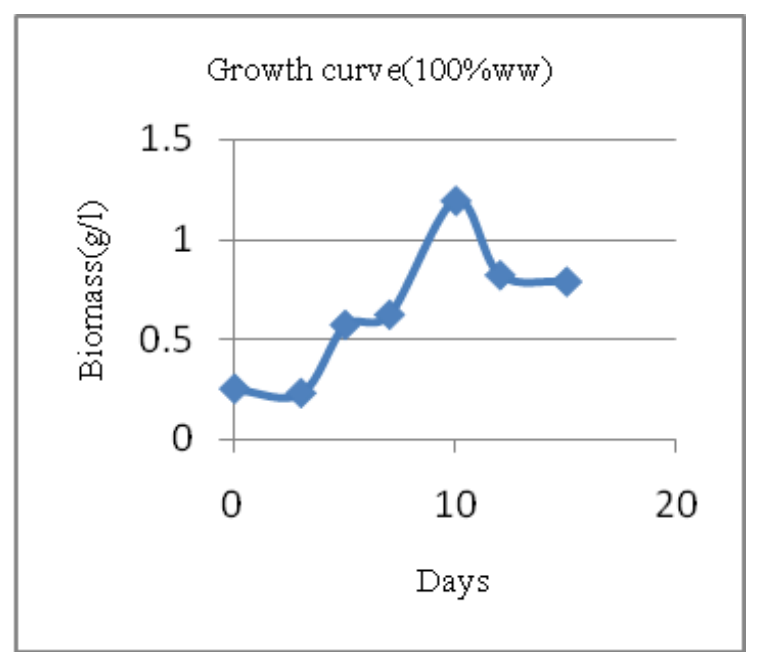

Fig 4 Showing the growth curve of $100 \% \mathrm{ww}=1.1926 \mathrm{~g} / \mathrm{l}$. 


\begin{tabular}{|c|c|c|c|c|c|c|}
\hline No. & Chemical & $\mathrm{mg} / \mathrm{lt}$ & & $\begin{array}{l}\text { Logarithmically } \\
\text { growing cells }\end{array}$ & $\begin{array}{l}\text { Late- } \\
\text { logarithmically } \\
\text { growing cells } \\
\end{array}$ & $\begin{array}{l}\text { Stationary } \\
\text { phase cells }\end{array}$ \\
\hline 1 & $\begin{array}{l}\mathrm{CO}\left(\mathrm{NO}_{3}\right)_{2} \\
6 \mathrm{H}_{2} \mathrm{O}\end{array}$ & 4.9 & $\begin{array}{c}\text { Initial dry cell weight } \\
\text { concentration }\left(X_{0}\right)\left[\mathrm{mg} \cdot \mathrm{mL}^{-1}\right]\end{array}$ & 2.07 & 2.03 & 1.95 \\
\hline 2 & $\mathrm{H}_{3} \mathrm{BO}_{3}$ & 114.2 & $\begin{array}{c}\text { Initial hydrogen production } \\
\text { rate } \\
\left(r_{\mathrm{H} 2,0}\right)\left[\mathrm{mmol} \mathrm{mL}^{-1} \mathrm{~h}^{-1}\right]\end{array}$ & 0.025 & 0.031 & 0.027 \\
\hline 3 & $\mathrm{ZnSO}_{4} \cdot 7 \mathrm{H}_{2} \mathrm{O}$ & 88.2 & $\begin{array}{c}\text { Deactivation rate constant }(k) \\
{\left[\mathrm{h}^{-1}\right]}\end{array}$ & 0.017 & 0.019 & 0.006 \\
\hline 4 & EDTA & 500 & $\begin{array}{l}\text { Number of moles of } \\
\text { hydrogen per culture volume } \\
\text { at } 96 \mathrm{~h}\left(y_{\mathrm{H} 2,1}\right)\left[\mathrm{mmol} \mathrm{mL}^{-1}\right]\end{array}$ & 1.48 & 1.79 & 1.97 \\
\hline 5 & $\mathrm{KH}_{2} \mathrm{PO}_{4}$ & 1250 & $\begin{array}{l}\text { Attainable number of moles } \\
\text { of hydrogen per culture } \\
\text { volume }\left(y_{\mathrm{H} 2, \mathrm{f}}\right)\left[\mathrm{mmol} \mathrm{mL}^{-1}\right]\end{array}$ & 1.86 & 2.18 & 4.24 \\
\hline 6 & $\mathrm{FeSO}_{4} \cdot 7 \mathrm{H}_{2} \mathrm{O}$ & 49.8 & Specific death rate $\left(K_{\mathrm{d}}\right)\left[\mathrm{h}^{-1}\right]$ & 0.00076 & 0.0011 & 0.0026 \\
\hline 7 & $\mathrm{MgSO}_{4} \cdot 7 \mathrm{H}_{2} \mathrm{O}$ & 1000 & $\begin{array}{l}\text { Number of moles of lactate } \\
\text { per dry cell weight at } 96 \mathrm{~h} \\
{\left[\mathrm{mmol} \mathrm{mg}^{-1}\right]}\end{array}$ & 0.0308 & 0.0323 & 0.188 \\
\hline 8 & $\mathrm{KNO}_{3}$ & 1250 & $\begin{array}{c}\text { Dry cell weight concentration } \\
\text { at } 96 \mathrm{~h} \\
{\left[\mathrm{mg} \mathrm{mL}^{-1}\right]}\end{array}$ & 1.95 & 1.86 & 1.49 \\
\hline 9 & $\mathrm{CuSO}_{4} .5 \mathrm{H}_{2} \mathrm{O}$ & 15.7 & $\begin{array}{l}\text { Lactate concentration at } 96 \mathrm{~h} \\
{\left[\mathrm{mmol} \mathrm{mL}^{-1}\right]}\end{array}$ & 0.20 & 0.26 & 0.48 \\
\hline 10 & $\mathrm{MnCl}_{2} \cdot 4 \mathrm{H}_{2} \mathrm{O}$ & 14.2 & $\begin{array}{l}\text { Acetate concentration at } 96 \mathrm{~h} \\
{\left[\mathrm{mmol} \mathrm{mL}^{-1}\right]}\end{array}$ & 0.05 & 0.21 & 0.80 \\
\hline
\end{tabular}

Table 2: Results obtained from the grit chamber.

\begin{tabular}{|l|l|c|c|c|c|}
\hline $\begin{array}{l}\text { \% of waste } \\
\text { water }\end{array}$ & $\begin{array}{l}\text { Biomass } \\
(\mathrm{g} / \mathrm{l})\end{array}$ & $\begin{array}{c}\text { \% of lipid } \\
\text { Accumulation }\end{array}$ & $\begin{array}{c}\text { COD }(\% \\
\text { of } \\
\text { Reductio } \\
\mathrm{n})\end{array}$ & $\begin{array}{c}\text { Nitrogen }(\% \\
\text { of } \\
\text { Reduction) }\end{array}$ & $\begin{array}{c}\text { Phosphorous (\% of } \\
\text { Reduction) }\end{array}$ \\
\hline 25 & 0.8096 & 7 & 38.86 & 90 & 18.39 \\
\hline 50 & 1.3606 & 13.85 & 72.83 & 60 & 63.81 \\
\hline 75 & 1.11 & 12.27 & 42.7 & 40 & 35.24 \\
\hline 100 & 1.326 & 9.25 & 49.86 & 20 & \\
\hline
\end{tabular}

Table 3: Results obtained from the areation tank .

\begin{tabular}{|l|l|c|c|c|c|}
\hline $\begin{array}{l}\text { \% of waste } \\
\text { water }\end{array}$ & Biomass (g/l) & $\begin{array}{c}\text { \% of lipid } \\
\text { Accumulation }\end{array}$ & $\begin{array}{c}\text { COD (\% } \\
\text { of } \\
\text { Reduction } \\
\text { ) }\end{array}$ & $\begin{array}{c}\text { Nitrogen }(\% \\
\text { of } \\
\text { Reduction) }\end{array}$ & $\begin{array}{c}\text { Phosphorous (\% of } \\
\text { Reduction) }\end{array}$ \\
\hline 25 & 1.2506 & 11.2 & 47.85 & 10.81 & 26.67 \\
\hline 50 & 1.316 & 16.34 & 65.23 & 37.79 & 60 \\
\hline 75 & 1.2476 & 12.84 & 52.37 & 33.34 & 43.34 \\
\hline 100 & 0.8436 & 10.06 & 42.09 & 40.48 & 64 \\
\hline
\end{tabular}

Table 4: Results obtained from the secondary clarifier.

\begin{tabular}{|l|l|c|c|c|c|}
\hline $\begin{array}{l}\text { \% of waste } \\
\text { water }\end{array}$ & Biomass (g/l) & $\begin{array}{c}\text { \% of lipid } \\
\text { Accumulation }\end{array}$ & $\begin{array}{c}\text { COD (\% } \\
\text { of } \\
\text { Reductio } \\
\mathrm{n})\end{array}$ & $\begin{array}{c}\text { Nitrogen }(\% \\
\text { of } \\
\text { Reduction) }\end{array}$ & $\begin{array}{c}\text { Phosphorous (\% of } \\
\text { Reduction) }\end{array}$ \\
\hline 25 & 1.108 & 12.8 & 41.63 & 62.5 & 46 \\
\hline 50 & 1.5008 & 19.36 & 76.93 & 81 & 68.2 \\
\hline 75 & 0.9647 & 12.58 & 64.7 & 80 & 55.8 \\
\hline 100 & 1.1926 & 14.67 & 60.04 & 84 & 46.22 \\
\hline
\end{tabular}

Table (1) shows the result table of grit chamber, table (2) shows the result table foe the sample from the secondary shows the result for the sample from areation tank, table (3) clarifier., indicating biomass growth, \% of lipid 
accumulation, \% of COD reduction and elements such as phosphorous and nitrogen removal.

\section{PRODUCTION OF BIODIESEL}

As is evident from table (2) ,(3), and (4).., optimum condition for lipid and biomass concentration were: sample from secondary clarifier of $50 \%$ waste water combination. The alga was grown under these condition in 1001 open pond. The lipids were extracted using chloroform : methanol (2:1) and subjected to acid catalyzed esterification in lab scale reactor. Different concentrations of methanol and $\mathrm{H}_{2} \mathrm{SO}_{4}$ were used as depicted in the table. In a given run, lipid were transferred to reactor along with $\mathrm{H}_{2} \mathrm{SO}_{4}$ and methanol. The temperature was set at $65^{\circ} \mathrm{C}$ and the contents stirred for $1.5 \mathrm{~h}$. after the reaction hexane was added in the ratio of $0.2 \mathrm{ml}$ hexane $/ \mathrm{ml}$ of reaction mixture and stirred at $500 \mathrm{rpm}$ in a magnetic stirrer. Following mixing, the contents were transferred to separating funnel. The upper hexane phase containing FAME (biodiesel) was separated and hexane was separated by rotovac. The weight of biodiesel produced was noted and yield was calculated as ,

Yield of biodiesel $(\mathrm{g}$ biodiesel/g lipid $)=\mathrm{g}$ of FAME produced $* 100$

$$
\mathrm{g} \text { of lipid used }
$$

Table 5: amount of lipids used $=1 \mathrm{~g}$, temperature $=65^{\circ} \mathrm{C}$

\begin{tabular}{|l|l|}
\hline $\begin{array}{l}\text { Weight ratio } \\
\text { of methanol } \\
\text { to lipid }\end{array}$ & Yield of biodiesel \\
\hline $20: 1$ & 72.3 \\
\hline $30: 1$ & 76.5 \\
\hline $40: 1$ & 81.3 \\
\hline $50: 1$ & 88.6 \\
\hline $60: 1$ & 92.6 \\
\hline $70: 1$ & 90.3 \\
\hline $80: 1$ & 87.3 \\
\hline
\end{tabular}

As can be seen from table (5) optimum conditions for biodiesel production were: wt ratio of methanol : lipid = $60: 1$.

\section{CONCLUSION}

Comparing the results from table (2), (3) and (4) it is clear that secondary clarifier with $50 \%$ waste water combination shows the best results with the maximum biomass accumulation of $1.5008 \mathrm{~g} / \mathrm{l}$ and highest lipid accumulation with $19.36 \%$.

Using waste water as the medium for the growth of microalgae can reduce the capital cost, land required on the treatment of waste water and also over the bio diesel production plant setup. Micro algae has shown good growth in the waste water medium with the synergistic effect of treatment by the removal of the elements phosphorous, nitrogen and COD present in the effluents. It also cuts down the cost of chemicals used for the medium togrow grow the micro algae for the production of biodiesel.
Major focus is over the methods of harvesting of micro algae and the extraction of lipids which involves large amount of solvent. The growth of micro algae is also efficient in secreting the lipids that is grown in primary and secondary waste water.

\section{REFERENCES}

[1] Ashish Bhatnagar, Senthil Chinnaswamy, Manjinder Singh, K C Das. Renewable biomass production by mixotrophic algae in the presence of various carbon sources and wastewaters. Applied energy 88(2011) 3425-3431.

[2] Atefeh Ebrahimian, Hamid-Reza Kariminia, Manouchehr Vosoughi. Lipid production in mixotrophic cultivation of chlorella vulgaris in a mixture of primary and secondary municipal waste water. Elsevier renewable energy 71(2014)502-508.

[3] Bharat Gamia, J. P. Patelb, I.L.Kotharia .Cultivation of Chlorella protothecoides (ISIBES -101) under autotrophic and heterotrophic conditions for biofuel production. J. Algal Biomass Utln. 2014, 5 (2): 20 29 ISSN: 2229- 6905

[4] Farooq Ahmad, Amin U Khan and Abdullah Yasar .Basic principles of waste water treatment. Marcos von Sperling. ISBN: 184339162 7.Published by IWA publishing, London UK.The potential of chlorella vulgaris for waste water treatment and biodesel production. Pak. J. Bot., 45(S1): 461-465, January 2013.

[5] Fatima Zahra Mennaa, Zouhayr Arbib, Jose Antonio Perales. Urban wastewater treatment by seven species of microalgae and an algal bloom: biomass production, N, P removal kinetics and harvestability. Water research 83(2015) 42-51.

[6] Fiona Lynch, Anita Santana sanchez, Mikael Jamsa, Kaarina Sivonen, Eva Mari Aro, Yagut Allahverdiyeva. Screening native isolates of cyanobacteria and a green alga for integrated waste water treatment, biomass accumulation and neutral lipid production. Algal research 11(2015) 411-420.

[7] Liang Wang, min min, Yecong Li, Paul Chen, Yifeng Chen, Yuhuan Liu, Yingkuan wang, Roger Ruan. Cultivation of green algae Chlorella sp. In different waste waters from municipal waste water treatment. Appl biochem Biotechnol DOI 10.1007/s12010- 009$8866-7$

[8] Sema Sirin, Mika Sillanpaa. Cultivating and harvesting of marine alga Nanochloropsis oculata in local municipal waste water for bio diesel. Bioresource technology 191(2015)79-87.

[9] Suzana Wahidin, Ani Idris, Sitti Raehanah Muhamad Shaleh. Rapid bio diesel production using wet micro algae via microwave irradiation. Energy conversion and management 84(2014) 227-233.

[10] Sheng-Yi Chiu, Chien-Ya Kao, Tsai-Yu Chen, Yubin Chang, Chiu-Mei Kuo, Chih-Sheng Lin. Cultivation of microalgal chlorella for biomass and lipid production using wastewater as nutrient resource. Bioresource technology 184(2015)179-189. 
[11] S.Venkata Mohan, M.V. Rohit, P.Chiranjeevi, Rashmi Chandra, B.Navneeth. Heterotrophic microalgae cultivation to synergise bio diesel production with waste remediation: process and perspectives.

[12] Shih-Hsin Ho, Akihiko Kondo, Tomohisa Hasunuma, Jo-Shu Chang. Engineering stratergies for improving the $\mathrm{CO} 2$ fixation and carbohydrate productivity of Scenedesmus obliquus CNW-N used for bio ethanol fermentation. Bioresource technology 143(2013)163171.

[13] Yeoung- Sang Yun, Sun Bok Lee, Jong Moon Park, Choong-I1 Lee, Ji-Won Yang. Carbon dioxide fixation by algal cultivation using waste water nutrients. J. Chem. Tech. Biotschnol. 1997, 67 451455.

[14] Sema S, Mika Sillanpaa. Cultivating and harvesting of marine alga Nannochloropsis oculata in local municipal wastewater for biodiesel. Laboratory of Green Chemistry, Lappeenranta University of Technology (LUT), Sammonkatu 12, 50130 Mikkeli, Finland. Bioresource technology 191 (2015) 79-87. 